\section{Downy Mildew Disease Progress in Resistant and Susceptible Cucumbers Tested in the Field at Different Growth Stages}

\author{
Kyle M. VandenLangenberg and Todd C. Wehner ${ }^{1}$ \\ Department of Horticultural Science, North Carolina State University, \\ Raleigh, NC 27695-7609
}

Additional index words. Cucumis sativus, Pseudoperonospora cubensis, disease, adult stage resistance

\begin{abstract}
Downy mildew, caused by the oomycete pathogen Pseudoperonospora cubensis (Berkeley \& Curtis) Rostov, is a major foliar disease of cucumber. Ten years after the reemergence of $\boldsymbol{P}$. cubensis, downy mildew continues to be a major threat to cucumber production in the United States. Cucumber accessions with high levels of resistance have been identified. Development of cultivars with high levels of resistance remains an important objective of cucumber breeding programs. We tested a set of cucumber cultigens, including highly resistant $P I$ accessions and susceptible control lines, to observe the effect of plant age on resistance. Cultigens responded differently to disease across plant developmental stages. In general, older plants had more disease symptoms, even those classified as resistant, such as PI 197088. However, PI 330628 and PI 605996 held their resistance even at late developmental stages. It is possible that these lines were resistant at late stages due to other factors, such as their rapid, indeterminate growth, that allows them to outgrow the disease. However, although PI 197088 appears to have a rapid, indeterminate growth habit, it did not have more resistance at later stages of plant maturity. Regardless of the mechanism involved, plant breeders should use the genetic resistance in PI 330628 and PI 605996 over PI 197088.
\end{abstract}

Cucumber (Cucumis sativus L.) is a major vegetable crop. The crop is cultivated in temperate and tropical countries and is the fourth most widely grown vegetable crop behind tomato (Lycopersicon esculentum Mill.), cabbage (Brassica oleracea var. capitata L.), and onion (Allium cepa L.) (Tatlioglu, 1993). In 2013, the U.S. farm value of cucumber was $\$ 363$ million, with $3.59 \times 10^{8} \mathrm{~kg}$ produced for the fresh and processing market (USDA, 2013). In North Carolina, in 2012, the fresh and processing cucumber market was valued at \$29 million (USDA, 2012).

Downy mildew, caused by the oomycete pathogen $P$. cubensis Rostov, is a major foliar disease of cucumber (Palti and Cohen, 1980). The disease symptoms on cucumber are characterized by the appearance of small, water-soaked lesions on the underside of leaves. Lesions are often angular and bound by leaf veins, eventually turning chlorotic and necrotic. Heavy sporulation can be observed within the lesions on the abaxial leaf surface. The disease has been reported in over 80 countries on 20 genera, including 50 species of the Cucurbitaceae, causing significant economic losses (Lebeda, 1992; Lebeda and Widrlechner, 2003; Olczak-Woltman

Received for publication 2 Mar. 2016. Accepted for publication 23 June 2016.

${ }^{1}$ Corresponding author. E-mail: tcwehner@gmail. com.

984 resistances continue to develop, cultivars with genetic resistance are needed.

New sources of genetic resistance (reduced leaf damage) and tolerance (high yield in the presence of disease) to the new race(s) of downy mildew in the United States were identified in a germplasm screening study and a multiyear re-evaluation of the most resistant and susceptible cultigens conducted at North Carolina State University (Call et al., 2012). Several cultigens were identified with high levels of resistance to the new downy mildew. Among these cultigens, considerable attention has been given to PI 197088. This accession is being used in breeding efforts as the source of high levels of resistance and the inheritance appears to be quantitative (Call, 2012; VandenLangenberg, 2014). Interestingly, the most resistant cultigens identified by Call et al. (2012), were only moderately resistant in the downy mildew screening of Wehner and Shetty (1997). It is likely that the change in the pathogen population in 2004 altered the rankings of these cultigens.

Adult plant resistance has been observed in several crop-disease interactions (Chen, 2005; Coelho and Monteiro, 2003; Shaik, 1985). However, to our knowledge, it has not been reported in cucumber. It is possible that the new resistance present in several PI accessions is a form of adult plant resistance. A better understanding of the pattern of resistance to the new downy mildew will help inform breeders and growers on best practices. The objective of this study was to better understand the interaction between the new race(s) of downy mildew and the newly identified, highly resistant cucumber cultigens, and to assess the presence of adult plant resistance.

\section{Materials and Methods} duction areas (Cohen, 1981; Colucci and Holmes, 2010). Before 2004, it was possible to control epidemics of cucumber downy mildew by growing resistant cultivars. However, a resurgence of the disease in 2004 and subsequent breakdown of the resistance resulted in yield losses of up to $40 \%$ (Colucci et al., 2006). Presently, 12 years after the appearance of a new race of cucumber downy mildew, the disease continues to threaten production in warm humid regions around the world, including most production areas of the United States.

Development of new cultivars with high levels of resistance remains an important objective of cucumber breeding programs. Without high levels of resistance, expensive fungicide programs have been necessary to maintain fruit yield and quality. P. cubensis reproduces both sexually and asexually and is wind dispersed over long distances. Because of the potential for evolution in downy mildew, and the widespread use of fungicides to control the disease, it is likely that resistance to the fungicides will develop. Several studies published since 2004 report the development of resistance to systemic fungicides (Colucci and Holmes, 2007; Hausbeck and Cortright, 2009; Lebeda and Urban, 2007; Mitani et al., 2001). As fungicide
Production methods and ratings. In Summer 2013 and 2014, nine cultigens were direct seeded into beds covered by black plastic mulch on raised beds at the Horticultural Crops Research Station at Clinton, NC. After germination, plots were thinned to five plants each. The soil type in Clinton was a mixture of Norfolk, Orangeburg, and Goldsboro loamy sand. The environment is subtropical during the main growing season, with high humidity and frequent rainfall. Cucumbers were grown using recommended horticultural practices as summarized by Schultheis (1990). Irrigation was applied as needed through plastic drip tape for a total of 25 to $40 \mathrm{~mm}$ per week. Plots consisted of five single-plant hills, with individual hills $0.6 \mathrm{~m}$ apart within the row. Border rows were planted using the susceptible cultivar Coolgreen about every third row to encourage the even spread of inoculum. No artificial inoculum was used in the field tests in North Carolina. Plots were exposed to natural epidemics encouraged by overhead irrigation during the growing season. The experiment design had multiple planting dates throughout the season. Plantings were made every 2nd week for six planting dates. The first 
plantings were on 9 May 2013 and 1 May 2014.

Disease severity was evaluated weekly in all planting dates after the onset of observable symptoms in the first planting date for six consecutive weeks. Ratings were based on the percentage of symptomatic leaf area [disease rating scale 0 to 9 , where $0=$ no damage, $1=1 \%$ to $10 \%, 2=11 \%$ to $20 \%, 3=$ $21 \%$ to $30 \%, 4=31 \%$ to $40 \%, 5=41 \%$ to $50 \%, 6=51 \%$ to $60 \%, 7=61 \%$ to $70 \%, 8=$ $71 \%$ to $80 \%$, and $9=81 \%$ to $100 \%$ (or dead)]; as described by Jenkins and Wehner (1983). The first ratings were taken on 11 July 2013 and 3 July 2014. The first rating day was exactly $62 \mathrm{~d}$ from planting in both years.

Plant material. Nine cucumber cultivars and PI accessions (hereafter collectively referred to as cultigens) differing in disease resistance were used to evaluate severity of disease at different life-cycle stages. Cultigens were chosen based on previous studies at North Carolina State University (Call, 2012; Call et al., 2012; Shetty et al., 2002; Wehner and Shetty, 1997). 'Wisconsin SMR 18' (Wisconsin AES) is highly susceptible, 'Poinsett 76' (Clemson and Cornell University) is moderately resistant, and 'Ashley' (Clemson University) is moderately susceptible. The PI accessions tested were the most resistant overall environments in a germplasm retest study (Call et al., 2012). They include PI 197085, PI 197086, PI 197088, PI 330628, PI 432875, and PI 605996.

Experiment design. We planted nine cultigens (subplots) in each of four replicates through time (planting date) using a split-plot design. In this way, plants in each subsequent planting (main plot) were at an earlier stage of development when inoculum arrived. To observe the true effect of plant age on resistance, we rated the entire study multiple times through the main infection season. A single rating of the entire experiment represents a snapshot of resistance expression on a set of cultigens at different stages of plant development. For example, our fourth rating in 2014 taken on 24 July was $14,28,42,56$, 70 , and $84 \mathrm{~d}$ after planting each sequential set of plots. This range of dates represents a high degree of spread in plant development stage, from first true leaf $(14 \mathrm{~d})$, full flower (28 d), early fruit set (42 d), late fruit set (56 d), early seed maturity (70 d), and late seed maturity (84 d).

To study the effect of plant stage on resistance, one must look at a set of cultigens at different stages of growth, all rated at the same time. For that, we used the fourth rating, since it had the best array of growth stages in both years. Earlier ratings lacked plants that were at the seed-set stage, whereas later ratings lacked plants at the preflower stage.

Statistical analysis of field data. Data were analyzed using analysis of variance (ANOVA) and regression analysis in the statistical packages JMP Pro 10 (SAS Institute Inc., Cary, NC), R (R Development Core Team, 2014) and SAS v9.4 (SAS Institute Inc., 2013). Before analysis, data were checked for normality. Residual plots had a random distribution, indicating that the statistical model was valid and its assumptions were met (Fernandez, 1992).

\section{Results and Discussion}

Severity of downy mildew was higher in 2013 than in 2014 when comparing mean disease severity pooled overall planting dates (Table 1). It is possible that the environment was more conducive to disease development in 2013 than in 2014, resulting in higher overall ratings. In general, 2013 was a wetter year than 2014, an environmental condition that promotes the spread of downy mildew.
Because of disease intensity differences between years, we analyzed the data separately between years to highlight any differences that disease intensity may cause. However, in areas of our report where no major differences appeared in our analysis, we pooled over years for simplicity.

All model effects were significant in our analysis of the fourth rating date in both 2013 and 2014, including planting date, cultigen, and the planting date by cultigen interaction (Table 2). Mean squares for planting date were 55 and 29 times higher than the planting date by cultigen interaction in 2013 and 2014, respectively. However, a significant planting

Table 1. Mean disease severity for resistance of cucumber cultivars by year $(2013,2014)$ at Clinton, NC, for each of six ratings. ${ }^{\mathrm{z}}$

\begin{tabular}{|c|c|c|c|c|c|c|c|c|}
\hline \multirow[b]{2}{*}{ Cultigen } & \multirow[b]{2}{*}{$\mathrm{N}$} & \multicolumn{6}{|c|}{ Rating $^{\mathrm{y}}$} & \multirow[b]{2}{*}{ Mean } \\
\hline & & 1 & 2 & 3 & 4 & 5 & 6 & \\
\hline \multicolumn{9}{|l|}{2013} \\
\hline Ashley & 48 & 5.69 & 4.63 & 4.85 & 3.50 & 5.00 & 6.46 & 5.02 \\
\hline PI 197085 & 48 & 3.06 & 2.45 & 2.80 & 1.88 & 2.71 & 4.88 & 2.96 \\
\hline PI 197086 & 48 & 2.69 & 2.55 & 2.25 & 1.67 & 3.17 & 5.50 & 2.97 \\
\hline PI 197088 & 48 & 3.56 & 3.20 & 3.90 & 2.88 & 3.67 & 5.67 & 3.81 \\
\hline PI 330628 & 48 & 1.63 & 1.75 & 2.25 & 1.70 & 2.35 & 3.91 & 2.26 \\
\hline PI 432875 & 48 & 3.06 & 3.60 & 3.75 & 2.96 & 3.38 & 5.22 & 3.66 \\
\hline PI 605996 & 48 & 3.06 & 2.85 & 2.55 & 1.71 & 2.33 & 3.88 & 2.73 \\
\hline Poinsett 76 & 48 & 3.69 & 3.85 & 4.47 & 3.04 & 3.67 & 6.25 & 4.16 \\
\hline Wisconsin SMR 18 & 48 & 6.67 & 5.63 & 5.84 & 4.78 & 6.30 & 6.96 & 6.03 \\
\hline Mean & & 3.68 & 3.39 & 3.63 & 2.68 & 3.62 & 5.41 & 3.73 \\
\hline F ratio $^{x}$ & & 9.85 & 10.16 & 10.75 & 12.81 & 6.77 & 7.39 & 22.49 \\
\hline \multicolumn{9}{|l|}{2014} \\
\hline Ashley & 48 & 2.00 & 3.95 & 3.42 & 4.67 & 3.67 & 3.58 & 3.62 \\
\hline PI 197085 & 48 & 1.00 & 1.61 & 1.95 & 2.77 & 3.09 & 2.73 & 2.21 \\
\hline PI 197086 & 48 & 1.00 & 1.25 & 1.58 & 2.50 & 2.58 & 1.67 & 1.85 \\
\hline PI 197088 & 48 & 1.29 & 2.24 & 2.05 & 3.43 & 3.81 & 2.11 & 2.60 \\
\hline PI 330628 & 48 & 0.74 & 1.17 & 1.57 & 2.82 & 2.77 & 1.90 & 1.89 \\
\hline PI 432875 & 48 & 1.00 & 2.28 & 2.10 & 3.67 & 3.57 & 2.44 & 2.53 \\
\hline PI 605996 & 48 & 1.00 & 2.05 & 43 & 2.74 & 2.91 & 1.82 & 2.08 \\
\hline Poinsett 76 & 48 & 1.05 & 3.65 & 2.79 & 3.88 & 3.46 & 2.92 & 3.03 \\
\hline Wisconsin SMR 18 & 48 & 3.25 & 5.40 & 4.63 & 6.17 & 5.21 & 5.50 & 5.05 \\
\hline Mean & & 1.37 & 2.62 & 2.39 & 3.63 & 3.45 & 2.74 & 2.76 \\
\hline $\mathrm{F}$ ratio & & 24.36 & 21.41 & 20.40 & 15.51 & 7.32 & 6.72 & 31.84 \\
\hline
\end{tabular}

${ }^{\mathrm{z}}$ Data are from four replications pooled overall planting dates. Disease assessment scale adopted for evaluating cucumber for resistance to downy mildew: 0 to 9 [where $0=$ no damage, $1=1 \%$ to $10 \%, 2=$ $11 \%$ to $20 \%, 3=21 \%$ to $30 \%, 4=31 \%$ to $40 \%, 5=41 \%$ to $50 \%, 6=51 \%$ to $60 \%, 7=61 \%$ to $70 \%, 8=71 \%$ to $80 \%$, and $9=81 \%$ to $100 \%$ (or dead)].

${ }^{y}$ Ratings occurred weekly starting with the onset of the first observable symptoms in the first planting date. ${ }^{x}$ Reported statistic is the model's F ratio from the model: Rating $=$ Date + Rep $($ Date $)+$ Cult + Date $\times$ Cult .

Table 2. Analysis of variance of the downy mildew disease severity by year for the fourth rating date at Clinton, NC, in 2013 and $2014 .^{2}$

\begin{tabular}{|c|c|c|c|c|c|}
\hline Source of variation & $\mathrm{df}$ & Sum of squares & Mean square & $\mathrm{F}$ & $P$ \\
\hline \multicolumn{6}{|l|}{2013} \\
\hline Planting date & 5 & 558.10 & 111.62 & 53.13 & $<0.01$ \\
\hline Error $\mathrm{A}^{\mathrm{y}}$ & 18 & 37.81 & 2.10 & & \\
\hline Cultigen & 8 & 2,127 & 26.41 & 26.56 & $<0.01$ \\
\hline Cultigen $\times$ date & 40 & 85.48 & 2.14 & 2.15 & $<0.01$ \\
\hline Error $\mathrm{B}^{\mathrm{x}}$ & 141 & 140.19 & 0.99 & & \\
\hline \multicolumn{6}{|l|}{2014} \\
\hline Planting date & 5 & 438.21 & 87.64 & 36.04 & $<0.01$ \\
\hline Error $\mathrm{A}^{\mathrm{y}}$ & 18 & 43.78 & 2.43 & & \\
\hline Cultigen & 8 & 113.36 & 14.17 & 9.87 & $<0.01$ \\
\hline Cultigen $\times$ date & 40 & 125.81 & 3.15 & 2.19 & $<0.01$ \\
\hline Error $\mathrm{B}^{\mathrm{x}}$ & 141 & 189.47 & 44 & & \\
\hline
\end{tabular}

${ }^{z}$ Data are from four replications on the fourth rating date. Disease assessment scale adopted for evaluating cucumber for resistance to downy mildew: 0 to 9 [where $0=$ no damage, $1=1 \%$ to $10 \%, 2=11 \%$ to $20 \%$, $3=21 \%$ to $30 \%, 4=31 \%$ to $40 \%, 5=41 \%$ to $50 \%, 6=51 \%$ to $60 \%, 7=61 \%$ to $70 \%, 8=71 \%$ to $80 \%$, and $9=81 \%$ to $100 \%$ (or dead) .

${ }^{\mathrm{y}}$ Error A is used to calculate $\mathrm{F}$ value and $P$ value for Date. Error A $=\operatorname{Rep}($ Date).

${ }^{x}$ Error B is used to calculate $\mathrm{F}$ value and $P$ value for Cultigen and Cultigen $\times$ Date. Error B $=\operatorname{Rep}(\mathrm{Cult} \times$ Date). 
date by cultigen interaction indicated that there were effects of plant development stage on downy mildew ratings (Fig. 1).

Disease severity increased with age of plant at time of exposure to downy mildew (Fig. 2). Regression analysis of the fourth rating date indicated differences among cultigens in the way plant age affects disease ratings (Table 3; Fig. 2). If adult stage resistances were present in a cultigen, then old plants would have lower ratings (have less disease) compared with young plants. For example, if only adult plants were resistant, we would expect planting date five to rate lower than planting date six on the same rating date. In both 2013 and 2014, older plants had higher ratings (had more disease severity) than younger plants on all occasions, indicating that adult stage resistance did not exist (Fig. 2).

Although no adult stage resistance was detected, some cultigens maintained their resistance longer than others (Fig. 2). Scaled effect estimates of all possible model terms in the regression analysis (intercept, days after planting, cultigens, and the days after planting by cultigen interaction) helped assess the impact of model terms on downy mildew ratings in comparison with the overall means. In our study, control cultigens 'Ashley', 'Poinsett 76', and 'Wisconsin SMR 18' had a positive (more disease) effect on downy mildew ratings compared with the overall mean. In contrast, resistant cultigens PI 197085, PI 197086, PI 330628, and PI 606996 had a negative (less disease) effect on downy mildew ratings. Interestingly, the highly resistant accession PI 197088, the resistant parent in several breeding projects, had no effect on downy mildew rating-with its mean rating over planting dates being about equal to the overall study mean on the fourth rating date (Table 3 ). The interaction between planting date and cultigen was found to be significant, consistent with the hypothesis that some cultigens would respond differently to disease at different stages of plant maturity (Table 2).

We observed that accessions PI 330628 and PI 605996 were better able to resist disease at later stages of development than the other cultigens tested using the scaled effect estimates of the regression model (Table 3). The regression slopes of PI 330628 and PI 605996 were less steep than the other cultigens tested (Fig. 2). The resistant accession PI 197088 was less able to resist disease (had a steeper regression line) at later stages of development in comparison with the other cultigens tested (Fig. 2; Table 3).

\section{Conclusions}

We detected no evidence of adult stage resistance to the new downy mildew in this set of cultigens. All cultigens rated higher at later stages of development. However, we did detect differences in the way some cultigens maintain their

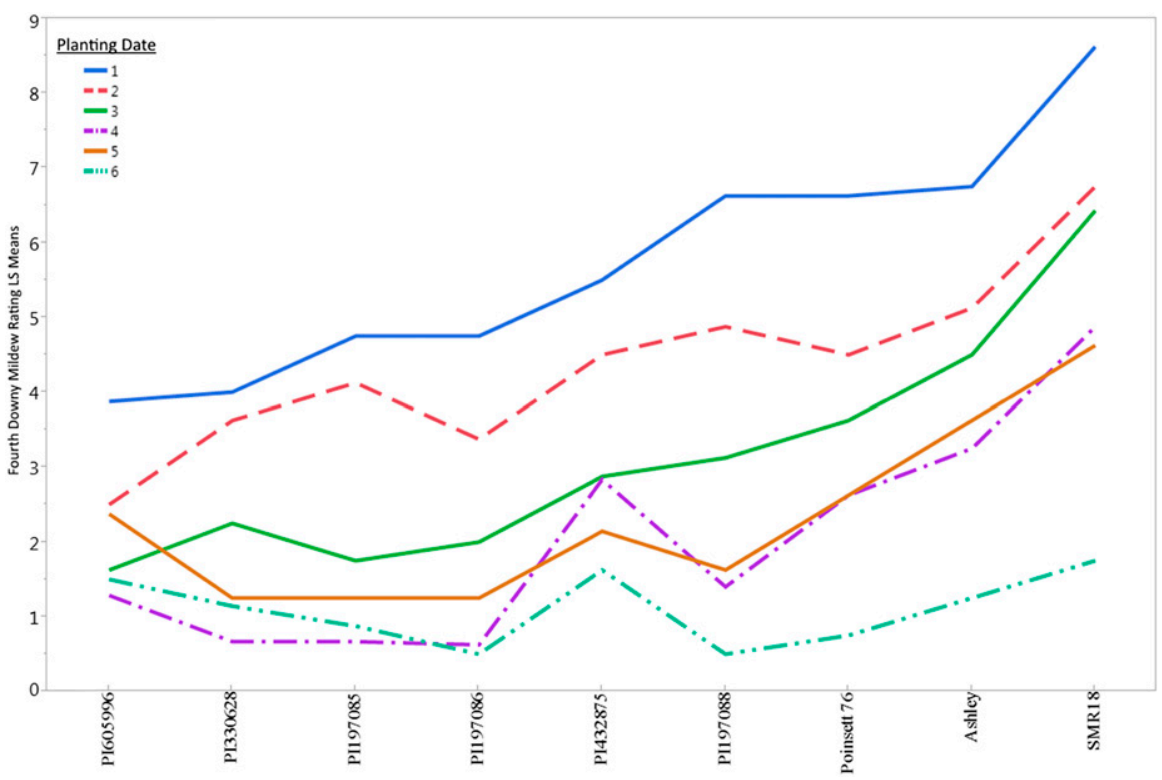

Fig. 1. Least squares mean plot of nine cultigens ( $x$ axis) by downy mildew rating on the fourth rating date ( $y$ axis) by six planting dates (different color lines). Areas where the lines cross represent a planting date by cultigen interaction. In general, only a mild amount of interaction between planting date and cultigen was observed. Data are from four replications over 2 years (2013 and 2014). Disease assessment scale adopted for evaluating cucumber for resistance to downy mildew: 0 to 9 [where $0=$ no damage, $1=1 \%$ to $10 \%, 2=11 \%$ to $20 \%, 3=21 \%$ to $30 \%, 4=31 \%$ to $40 \%, 5=41 \%$ to $50 \%, 6=51 \%$ to $60 \%, 7=61 \%$ to $70 \%, 8=71 \%$ to $80 \%$, and $9=81 \%$ to $100 \%$ (or dead)].

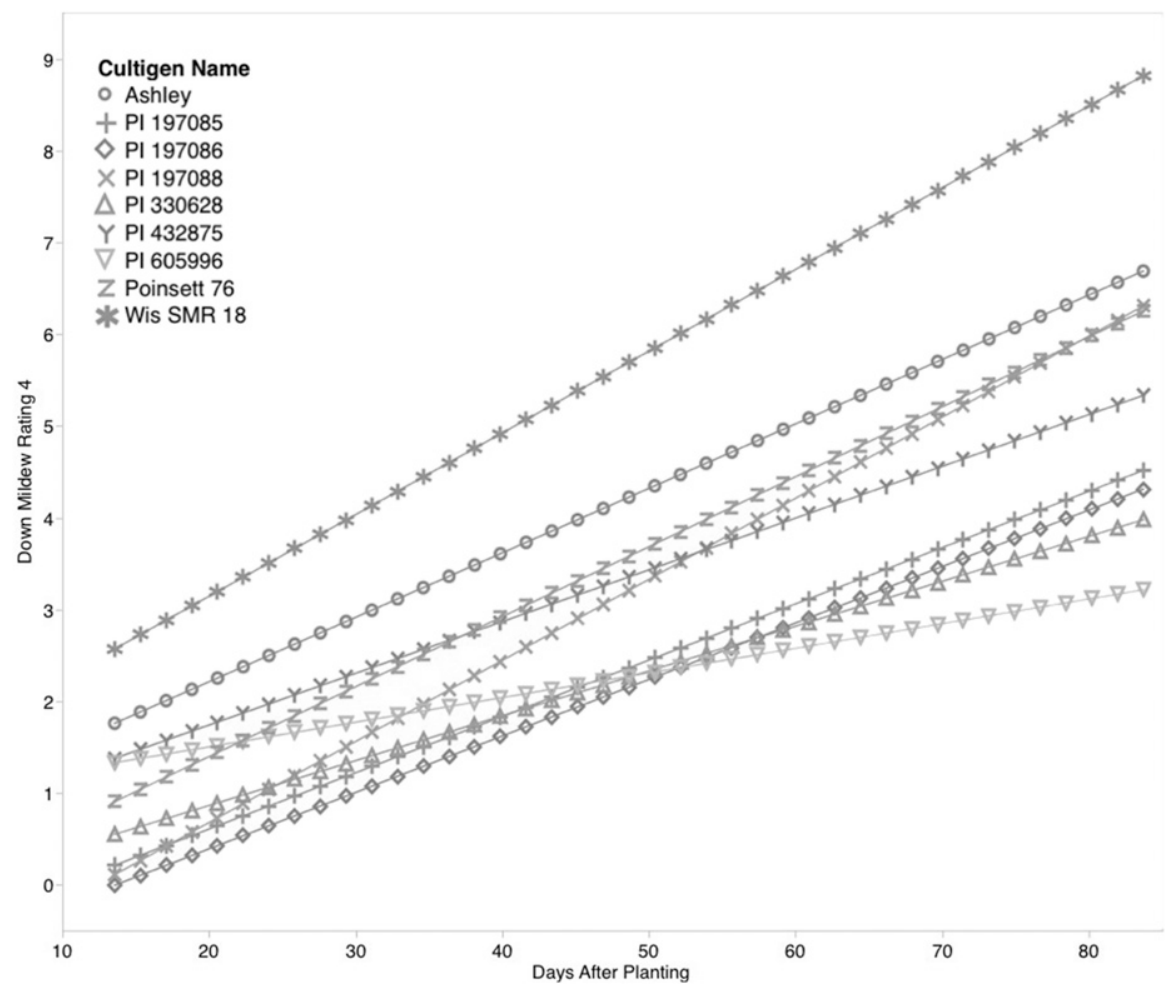

Fig. 2. Regression lines of the fourth downy mildew ratings for nine cultigens in 2 years (2013, $2014)$ plotted against days postsowing ( $x$ axis). Data are from four replications at $14,28,42,56$, 70 , and $84 \mathrm{~d}$ after planting. Disease assessment scale adopted for evaluating cucumber for resistance to downy mildew: 0 to 9 [where $0=$ no damage, $1=1 \%$ to $10 \%, 2=11 \%$ to $20 \%, 3=$ $21 \%$ to $30 \%, 4=31 \%$ to $40 \%, 5=41 \%$ to $50 \%, 6=51 \%$ to $60 \%, 7=61 \%$ to $70 \%, 8=71 \%$ to $80 \%$, and $9=81 \%$ to $100 \%$ (or dead)]. Least significant difference between cultigens is 1.595 $(P=0.05)$. 
Table 3. Scaled effect estimates of main and interacting factors for the fourth rating date of downy mildew pooled over years $(2013,2014)$.

\begin{tabular}{|c|c|c|c|c|c|}
\hline Model term ${ }^{z, y}$ & Scaled estimate & Plot estimate ${ }^{x}$ & SE & $t$ ratio & $P>|t|$ \\
\hline Intercept & 3.146 & & 0.064 & 49.24 & $<0.01$ \\
\hline Days after planting & 2.182 & & 0.093 & 23.51 & $<0.01$ \\
\hline \multicolumn{6}{|l|}{ Cultigens } \\
\hline PI 197085 & -0.842 & & 0.182 & -4.64 & $<0.01$ \\
\hline PI 197086 & -1.046 & & 0.178 & -5.87 & $<0.01$ \\
\hline PI 432875 & 0.117 & & 0.183 & 0.64 & 0.52 \\
\hline PI 605996 & -0.930 & & 0.180 & -5.17 & $<0.01$ \\
\hline Poinsett 76 & 0.333 & & 0.178 & 1.87 & 0.06 \\
\hline Wisconsin SMR 18 & 2.377 & & 0.180 & 13.21 & $<0.01$ \\
\hline PI $197088 \times($ DayPostSow-48.9451) & 0.816 & & 0.262 & 3.11 & $<0.01$ \\
\hline PI $330628 \times($ DayPostSow-48.9451) & -0.524 & & 0.267 & -1.96 & 0.05 \\
\hline PI $432875 \times($ DayPostSow-48.9451) & -0.269 & & 0.264 & -1.02 & 0.31 \\
\hline PI $605996 \times($ DayPostSow-48.9451) & -0.271 & & 0.262 & -4.86 & $<0.01$ \\
\hline Poinsett $76 \times($ DayPostSow-48.9451) & 0.404 & t & 0.262 & 1.55 & 0.12 \\
\hline Wisconsin SMR $18 \times($ DayPostSow-48.9451) & 0.839 & 7 & 0.262 & 3.21 & $<0.01$ \\
\hline
\end{tabular}

${ }^{2}$ Data are means over four replications taken on the fourth rating date. Disease assessment scale adopted for evaluating cucumber for resistance to downy mildew: 0 to 9 [where $0=$ no damage, $1=1 \%$ to $10 \%, 2=11 \%$ to $20 \%, 3=21 \%$ to $30 \%, 4=31 \%$ to $40 \%, 5=41 \%$ to $50 \%, 6=51 \%$ to $60 \%, 7=61 \%$ to $70 \%, 8=71 \%$ to $80 \%$, and $9=81 \%$ to $100 \%$ (or dead) $]$.

${ }^{\mathrm{y}}$ Continuous factors are centered by mean and scaled by range/ 2 .

${ }^{x}$ The plot estimate column graphically represents the relative amount of effect a model term has on the overall downy mildew rating, with longer bars representing a greater effect on the 0 to 9 rating scale. Bars to the right represent an increase in downy mildew rating, whereas bars to the left represent a decrease in downy mildew rating.

resistance over time. PI 330628 and PI 605996 were considered resistant at later development stages than other cultigens. The observation that some cultigens in our study responded differently to disease at different plant developmental stages may be due to several factors. PI 330628 and PI 605996 were capable of resisting downy mildew in later growth stages. Their overall vigor and large plant size may give them the ability to outgrow the disease. It is also possible that these cultigens are resistant to other diseases (present later in the season) that were not quantified in this study. It is concerning that the resistant accession PI 197088 appears to develop disease symptoms faster than other resistant PI accessions since it is being used for the development of commercial cultivars with high levels of resistance.

These results should be verified in additional studies. The use of growth chambers would allow for better control of experimental results, as our results may be biased due the presence of other diseases with similar symptomologies as downy mildew. Plant breeders may wish to use PI 330638 or PI 605996 instead of PI 197088 due to their ability to maintain a high level of resistance for weeks past flowering stage.

\section{Literature Cited}

Call, A.D. 2012. Inheritance of resistance to downy mildew in cucumber (Cucumis sativus L.) PI 197088 and effect of interaction of host plant resistance, fungicides, and environment on severity of downy mildew on cucumber. PhD Diss. North Carolina State Univ., Raleigh, NC.

Call, A.D., A.D. Criswell, T.C. Wehner, U. Klosinska, and E.U. Kozik. 2012. Screening cucumber for resistance to downy mildew caused by Pseudoperonospora cubensis (Berk. and Curt.) Rostov. Crop Sci. 52:577-592.

Chen, X.M. 2005. Epidemiology and control of stripe rust [Puccinia striiformis $\mathrm{f}$. sp. tritici] on wheat. Can. J. Plant Pathol. 27:314-337.

Coelho, P.S. and A.A. Monteiro. 2003. Expression of resistance to downy mildew at cotyledon and adult plant stages in Brassica oleracea $\mathrm{L}$. Euphytica 133:279-284.

Cohen, Y. 1981. Downy mildew of cucurbits, p. 636. In: D.M. Spencer (ed.). The downy mildews. Academic Press, New York, NY.

Colucci, S.J. and G.J. Holmes. 2007. Fungicide insensitivity and pathotype determination of Pseudoperonospora cubensis, causal agent of cucurbit downy mildew. Phytopathology 97:S24.

Colucci, S.J. and G.J. Holmes. 2010. Downy mildew of cucurbits. The plant health instructor. DOI: 10.1094/PHI-I-2010-0825-01.

Colucci, S.J., T.C. Wehner, and G.J. Holmes. 2006. The downy mildew epidemic of 2004 and 2005 in the eastern United States, p. 403-411. In: G.J. Holmes (ed.). Proc. Cucurbitaceae 2006 Asheville, NC.
Fernandez, G.C.J. 1992. Residual analysis and data transformations: Important tools in statistical analysis. HortScience 27:297300 .

Hausbeck, M.K. and B.D. Cortright. 2009. Evaluation of fungicides for control of downy mildew of pickling cucumber, 2007. Plant Dis. Mgt. Rpt. 3:V112.

Jenkins, S.F., Jr. and T.C. Wehner. 1983. A system for measurement of foliar disease in cucumbers. Cucurbit Genet. Coop. Rpt. 6:10-12.

Lebeda, A. 1992. Screening of wild Cucumis species against downy mildew (Pseudoperonospora cubensis) isolates from cucumbers. Phytoparasitica 20(3):203-210.

Lebeda, A. and J. Urban. 2007. Temporal changes in pathogenicity and fungicide resistance in Pseudoperonospora cubensis populations. Acta Hort. 731:327-336.

Lebeda, A. and M.P. Widrlechner. 2003. A set of Cucurbitaceae taxa for differentiation of $P$ seudoperonospora cubensis pathotypes. J. Plant Dis. Prot. 110:337-349.

Mitani, S., S. Araki, T. Yamaguchi, Y. Takii, T. Ohshima, and N. Matsuo. 2001. Biological properties of the novel fungicide cyazofamid against Phytophthora infestans on tomato and Pseudoperonospora cubensis on cucumber. Pest Mgt. Sci. 58:139-145.

Olczak-Woltman, H., J. Marcinkowska, and K. Niemirowicz-Szczytt. 2011. The genetic basis of resistance to downy mildew in Cucumis spp.-Latest developments and prospects. J. Appl. Genet. 52:249-255. 
Palti, J. and Y. Cohen. 1980. Downy mildew of cucurbits (Pseudoperonospora cubensis). The fungus and its hosts, distribution, epidemiology and control. Phytoparasitica 8:109-147.

R Development Core Team. 2014. R: A language and environment for statistical computing. $\mathrm{R}$ Foundation for Statistical Comp. 1 Aug. 2014. $<\mathrm{http}: / /$ www.R-project.org $>$.

SAS Institute Inc. 2013. SAS ${ }^{\circledR} 9.4$ guide to software updates. SAS Institute Inc., Cary, NC.

Schultheis, J.R. 1990. Pickling cucumbers. N.C. State Agr. Ext. Hort. Info. Lftt. No. 14-A.
Shaik, M. 1985. Race-nonspecific resistance in bean cultivars to races of Uromyces appendiculatus var. appendiculatus and its correlation with leaf epidermal characteristics. Phytopathology 75:478-481.

Shetty, N.V., T.C. Wehner, C.E. Thomas, R.W Doruchowski, and K.P.V. Shetty. 2002. Evidence for downy mildew races in cucumber tested in Asia, Europe, and North America. Sci. Hort. 94:231-239.

Tatlioglu, T. 1993. Cucumbers. In: G. Kalloo and B.O. Bergh (ed.). Genetic improvement of vegetable crops. Pergamon Press, New South Wales, Australia.
USDA, National Agricultural Statistics Service. 2012. Cucumbers: National Statistics. 9 Sept. 2014. <http://www.nass.usda.gov/>.

USDA, National Agricultural Statistics Service. 2013. Cucumbers: National Statistics. 9 Sept 2014. <http://www.nass.usda.gov/>.

VandenLangenberg, K.M. 2014. Studies on downy mildew resistance in cucumber (Cucumis sativus L.). PhD Diss., North Carolina State Univ., Raleigh, NC.

Wehner, T.C. and N.V. Shetty. 1997. Downy mildew resistance of the cucumber germplasm collection in North Carolina field tests. Crop Sci. 37:1331-1340. 